Marketing in Asia Group

\title{
Weeding out Deviant Workplace Behaviour in Downsized Organizations: The Role of Emotional Intelligence and Job Embeddedness
}

\author{
Mastura Mohd Yusof \\ Putra Business School, Universiti Putra Malaysia, Selangor, Malaysia
}

Jo Ann Ho

Faculty of Economics and Management, Universiti Putra Malayia, Selangor, Malaysia

Serene Ng Siew Imm

Faculty of Economics and Management, Universiti Putra Malaysia, Selangor, Malaysia

Dahlia Zawawi

Faculty of Economics and Management, Universiti Putra Malaysia, Selangor, Malaysia

\begin{abstract}
While job insecurity has been widely studied across various contexts, the empirical study within the Malaysian context remained scarce. This study was undertaken to investigate the effect of job insecurity on deviant workplace behaviour on employees from retrenching organizations. This study also explored the effects of emotional intelligence and job embeddedness as moderating variables. Respondents were selected from retrenching organizations located in Johore, Penang and Selangor as these three states had the highest number of retrenchment cases in the country. Hypotheses testing was carried out using partial least squares structural equation modelling (PLS-SEM), the SmartPLS version 2.0. Overall, the results showed that job insecurity was negatively related to affective commitment and positively related to job-related tension. No relationship was detected between affective commitment and deviant workplace behaviour; however job-related tension correlated positively to deviant workplace behaviour. There was also a significant moderating influence of emotional intelligence on affective commitment and deviant workplace behaviour as well as on the relationship between job-related tension and deviant workplace behaviour. In addition, job embeddedness moderated the relationship between jobrelated tension and deviant workplace behaviour. The implications of the results to both theory and practice are discussed in this paper.
\end{abstract}

Keywords: Affective Commitment; Deviant Workplace Behaviour; Emotional Intelligence; Job Embeddedness; Job Insecurity; Job-Related Tension

Publication Details: Received 8 Feb 2019; Revised 18 Dec 2019; Accepted 22 Dec 2019 


\section{Introduction}

As one of the recurring effects of the 2008 global economic downturn, organizations have been retrenching, restructuring and merging with increasing frequency in order to reduce costs and increase short-term financial performance (Murphy, Burton, Henagon \& Briscoe, 2013). Such organizational changes are perceived as threats which can cause employees to feel insecure about their job. Various studies (e.g. Lawrence \& Robinson, 2007; Chiu \& Peng, 2008; Chirumbolo, 2015; Huang et al., 2010) have found employees responded to job insecurity by engaging in or developing deviant workplace behaviours. Deviant workplace behaviours are voluntary behaviours intended to harm both the people and the organization (Spector \& Fox, 2002). It consists of actions that can be as minor as leaving early from work, taking longer breaks, gossiping, or embarrassing co-workers to more serious actions such as sexual harassment, sabotages and thefts (Bennett \& Robinson, 2000). On the other hand, job insecurity is the feeling of helplessness as a result of the difference between the employee's desired employment condition and the actual condition that the employee is facing (Tian, Zhang, \& Zou, 2014). Past studies have documented that job insecurity affects employee's affective commitment while imposing stress on the employees (Ito \& Brotheridge, 2007; Konig, Probst, Staffen \& Graso, 2011; Tian et al., 2014; Kerse, Kocak \& Ozdemir, 2018) such that it triggers negative emotions such as deviant workplace behaviour within an employee (Murphy et al., 2013).

Despite extensive studies on the antecedents and consequences of job insecurity, very little research has investigated the contingencies affecting employees' decisions to engage in deviance workplace behaviour when faced with job insecurity. Past research has so far focused on individual factors, to act as moderators that may reduce the adverse effect of job insecurity. Among the individual factors that have been investigated are locus of control (Ashford, Lee \& Bobko, 1989; Naswall, Sverke \& Hellgren, 2005; Ito \& Brotheridge, 2007; Konig, Debus, Hausler, Lendenmann \& Kleinmann, 2010), organization-based self-esteem and proactive personality (Lin, Chen, Ashford, Lee \& Qian, 2018), self-esteem and optimism (Makikangas \& Kinnunen, 2003), coping styles like self-negative and positive affect (Roskies, LouisGuerin, \& Fournier, 1993; Mak \& Mueller, 2000; Naswall et al., 2005), coping strategies from a gender perspective (Menendez-Espina et al., 2019) and cultural values such as individualism and collectivism (Probst \& Lawler, 2006; Konig et al., 2011). However, these studies did not address the emotional states that arise from job insecurity or how emotions play a role in deviant workplace behaviour. According to Cheng, Huang, Lee, and Ren (2012), emotional intelligence has been posited to have a positive effect in dealing with stressful situations and a key factor to avert negative behaviours (Martin, Knopoff \& Beckman, 1998; Huy, 1999). Emotional intelligence refers to one's capability to comprehend emotions felt by other individuals and being able to feel and express suitable emotions (Mayer \& Salovey, 1997). It consists of inter-related capabilities that include the ability to identify one's own emotion and of others, to link the thinking process with emotional intelligence, to understand and manage the emotions of self and other individuals (Mayer \& Salovey, 1997). An increase in emotional intelligence has been said to reduce deviant workplace behaviours related to organizational tasks (Mayer, Salovey, \& Caruso, 2000; Robinson, Persich, Stawicki \& Krishnakumar, 2019; Al Ghazo, Suifan, \& Alnuaimi, 2019). 
Burton, Holtom, Sablynski, Mitchell, and Lee (2010) argued that even during negative times, individuals who were highly embedded would continue to put more effort in work to achieve their goals because they were highly involved with their organizations and had high expectations for a strong relationship with the organization in the future. Based on the argument by Burton et al., (2010) that job embeddedness is all about the tendency of an employee to stay with the job and their attachment towards the organization despite any negative events at the workplace, job embeddedness might act as a motivation to an employee to remain productive and positive; embedded employees are less likely to engage in deviant workplace behaviour during difficult times in the organization. The construct of job embeddedness is made of a wide range of factors influencing a person's decision to remain with a job. It includes how a person fits with the organization they work in as well as the community they live in, the links a person has with colleagues and community, and the sacrifices they have to bear upon leaving the organization and community (Mitchell, Holtom, Lee, Sablynski \& Erez, 2001). More recent research has expanded the concept of job embeddedness to further study its predictive capacity on work-related outcomes such as absenteeism, organizational citizenship behaviour (OCB), performance and innovative work behaviour (Sekiguchi, Burton \& Sablynski, 2008; Darrat, Amyx \& Bennett, 2017; Greene, Mero \& Werner, 2018; Susomrith \& Amankwaa, 2019) and employee's intention to leave (Mitchell et al., 2001; Yam \& Raybould, 2019). However, not much is known about the workplace behaviour of highly embedded employees who remain in organizations during the occurrence of negative events such as organization restructurings or retrenchments, specifically the impact of job embeddedness on employees' deviant workplace behaviour. Hence, this study aims at exploring the relationship of job insecurity and deviant workplace behaviour with the moderating effects of emotional intelligence and job embeddedness.

\section{Literature Review}

The purpose of this research is to enhance and test a conceptual model developed by Jordan, Ashkanasy, and Hartel (2002) in explaining employee's engagement in deviance workplace behaviour and investigate the influence of moderators in the proposed relationships of the model. While Jordan et al. (2002) proposed the conceptual model in 2002; there have been limited studies investigating the applicability of the proposed model (Van Zyl, Van Eeden \& Rothmann, 2013). In addition, this model closely supports our contention that job insecurity affects employee's affective commitment and imposes stress (in the form of job-related tension) on the employees (Ito \& Brotheridge, 2007; Konig, Probst, Staffen \& Graso, 2011; Tian et al., 2014; Kerse et al., 2018) such that it triggers negative emotions (i.e. deviant workplace behaviour) within an employee (Murphy et al., 2013). For these reasons, this model forms the research framework of our study.

The model developed by Jordan et al. (2002) is discussed and argued from the perspective that job insecurity would result in deviant workplace behaviour because it affected the employee's affective commitment and triggered job-related tension. However, it is the individual differences of emotional intelligence and job embeddedness that explain why certain employees, when faced with job security, engage in deviant workplace behaviour while some do not. 
Figure 1: Theoretical Framework (adapted from Jordan et al., 2002)

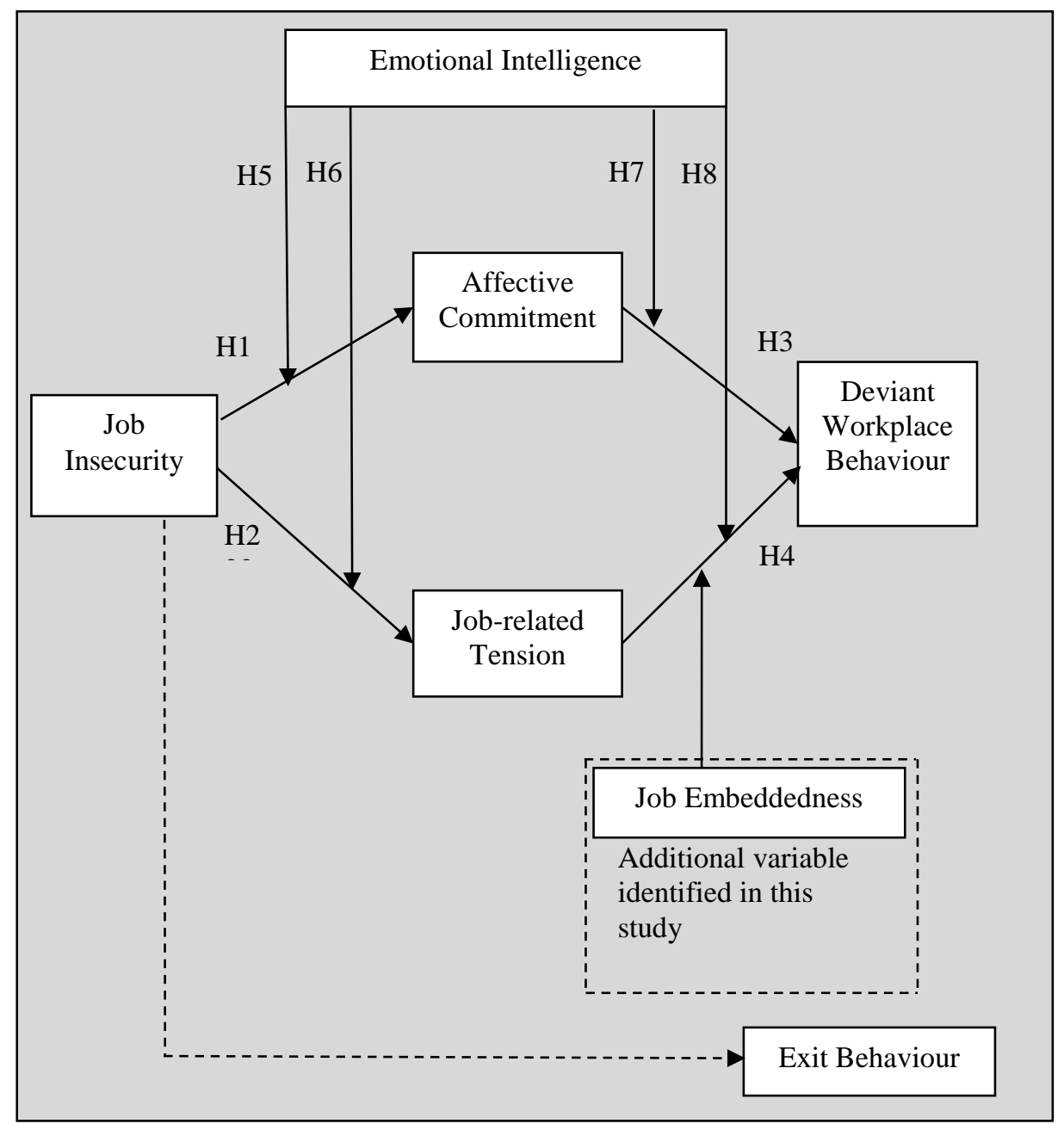

As an overarching theoretical framework, Jordan et al. (2002) drew on the theory by Ortony, Clore and Collins (1988) which theorized that emotions were triggered from valence reactions subsequent to the appraisal of a situation either being harmful or beneficial to the individual. The theory of proposed by Ortony et al. (1988) contains twenty-two emotions types that accounts for all ranges of human emotions categorized based on an individual's core appraisal patterns, i.e., the cognitive structural logics that an individual employs to interpret a situation. According to Ortony et al., (1988), these cognitions are determined by three aspects which are consequences of events, actions of agents, and aspects of objects. Based on this theory, this study proposed that the cognitive appraisal of job insecurity would lead to two emotional responses: affective commitment and job-related tension. In any event that an employee experiences job insecurity, he/she may appraise the situation as an undesirable event that disturbs their employment with the organization causing them to feel displease or distress, which in turn triggers job-related tension. In addition, an employee may disapprove the actions taken by the organization (the agent) which does not meet the employee's standard and as a result, no longer appraises the organization to be appealing. This results in a reduction of the employee's affective commitment. These two emotional reactions then lead to deviant workplace behaviour. 
Figure 2: A Simple Visualization of the OCC Model of Emotions (Ahmadpour, 2014)

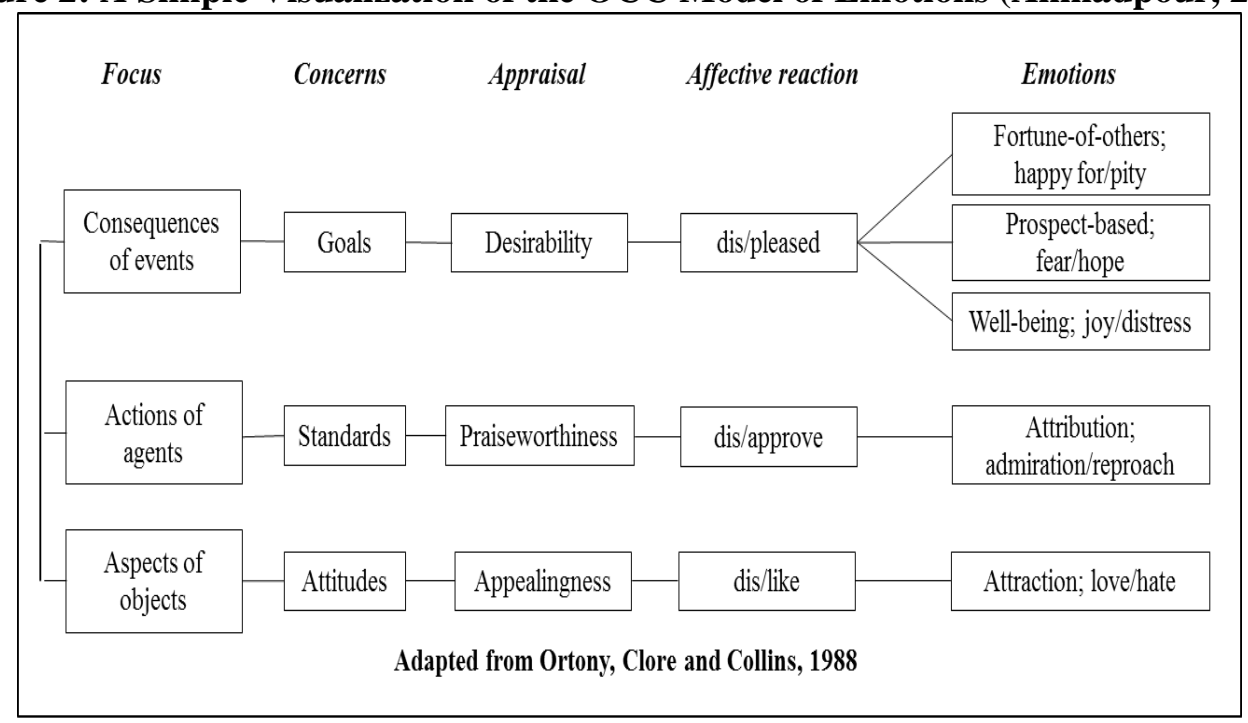

\section{Job Insecurity and Affective Commitment}

Job insecurity has been perceived to be an organizational stressor as it revolved around the possibility of losing a job or changes in job features (Huang et al., 2010; Lawrence \& Robinson, 2007). Past studies have reported that job insecurity reduces employee's affective commitment towards the organization (Ito \& Brotheridge, 2007; Tian et al., 2014; Kerse et al., 2018). Affective commitment is defined as the employee's emotional attachment to the organization in which an employee identifies with and enjoys being a member of the organization (Allen \& Meyer, 1990). According to Tian et al. (2014), job insecurity has a negative influence on affective commitment such that the negative emotions (anxiety, depression, frustration) arises from the appraisal of job insecurity may reduce an employee's level of affective attachment as they feel less attracted to remain in the organization (Tian et al., 2014). Due to this, job insecurity is expected to be negatively related to employee's affective commitment which leads to the development of the first hypothesis. This study proposes a negative relationship between job insecurity and affective commitment since job insecurity is a job stressor that results in uncertainty concerning the continuation of the job as it currently exists. Employees with high level of job insecurity would have less emotional attachment to the organization. As such, it is hypothesized that:

H1 There is a negative relationship between job insecurity and affective commitment.

\section{Job Insecurity and Job-related Tension}

Job insecurity causes tension which subsequently affects an employee's physical wellbeing (Hill, 2004). Job-related tension is one of the representations of job stress alongside other negative feelings such as anxiety, frustration, worry, emotional exhaustion, and distress (Van Voorhis et al., 1991; Grossi et al., 1996). Moreover, it has been documented in past studies that job insecurity reduces work health and employee's well-being as well as general physical health (Feng, Lu, \& Siu, 2008; Siu, 2013; Henseke, 2018). This is because having a steady job fulfils social and economic 
needs as the steady job acts as a source of income that provides the necessities in life. Furthermore, having a job allows an individual to make social contacts thus facilitating their own personal development (Meyer, Stanley, Herscovitch \& Topolnytsky, 2002; Selenko, Makikangas \& Stride, 2017). However, when an individual experiences uncertainty concerning the security of his/her job, it leads to frustration of being unable to fulfil one's social and economic needs, apart from the possibility of losing their source of income (De Witte, 1999). According to Lazarus and Folkman (1984), the anticipation of a stressful event leads to a similar level of anxiety or an even greater level than the actual event which may cause strain to an individual (Lazarus \& Folkman, 1984; Jex \& Beehr, 1991). Job insecurity which is the perceived threat of losing the job in the future may have detrimental consequences as the actual job loss itself (De Witte, 1999). The prolonged uncertainty that an individual feels when faced with job insecurity makes it difficult for the individual to cope, which consequently leads to heightened anxiety and impaired well-being (Lazarus \& Folkman, 1984). In other words, perceived job insecurity causes tension to the employees. Thus:

H2 There is a positive relationship between job insecurity and job-related tension.

\section{Affective Commitment and Deviant Workplace Behaviour}

In the context of commitment and deviant workplace behaviour, it is believed that organizational commitment is a potential factor of deviant workplace behaviour. However, the strength of the relationship may differ between the three constructs of commitment i.e. affective, normative and continuance commitment (Gill, Meyer, Lee, Shin \& Yoon 2011). Since affective commitment refers to the employee's emotional attachment to an organization (Allen \& Meyer, 1990), employees with high affective commitment would be more strongly attached to their organization, and as such are more likely to remain and contribute to the organization's success as compared to employees with low affective commitment (Meyer \& Allen, 1997). In addition, employees with strong affective commitment have been reported to experience positive affectivity and less negative affectivity than those with low affective commitment (Thoresen, Kaplan, Barsky, Warren \& de Chermont, 2003). This is because negative affectivity employees are more reactive to negative stimuli and are therefore more sensitive and tend to experience negative emotions such as anger, guilt, anxiety, sadness and rejection when faced with stressful situations (Penney \& Spector, 2005; Panaccio, Vandenberghe \& Ben Ayed, 2014).

Past studies (Samnani, Salamon \& Singh, 2014; Penney \& Spector, 2005) have found that employees with high negative affectivity were more likely to engage in deviant workplace behaviour because they viewed everything more negatively as compared to individuals with positive affectivity. In contrast, employees with high affective commitment were more inclined to experience positive affectivity and as such were less likely to engage in deviant workplace behaviour (Thoresen et al., 2003; Gill et al., 2011; Promsri, 2018). This is because affective commitment refers to the identification with the organization and employees high in affective commitment would enjoy their organizational membership and bounded by mutual trust and longterm dedication to the organization. Therefore, it is less likely for individuals with high affective commitment to be involved in activities that would tarnish the 
organization's image, as this will affect the employee's identification with the organization. Thus:

H3 There is a negative relationship between affective commitment and deviant workplace behaviour.

\section{Job-related Tension and Deviant Workplace Behaviour}

Job-related tension is a negative emotional experience as a result of a stimulus usually perceived to be harmful to the individual which then triggered a response aimed to end the emotional encounter (Van Graan, 1981). High levels of tension may harm workers' performance and result in negative behavioural and attitudinal work outcomes (Oplatka, 2009). Such outcomes are categorized by physical, psychological and behavioural reactions such as mental withdrawal from the job, reduced interactions with clients and co-workers, increased conflict with family and friends, absenteeism, substance abuse, turnover, burnout, health/medical problems (Lambert, Minor, Wells, \& Hogan, 2016). In addition, a number of studies have reported a correlation between experienced job stress and the occurrence of deviant workplace behaviour such as absenteeism, alcoholism, and substance abuse (Omar, Halim, Zainah \& Farhadi, 2011; Safaria, Othman \& Wahab, 2011; Nasurdin, Ahmad \& Razalli, 2014; Silva \& Ranasinghe, 2017).

According to the social exchange theory, beneficial exchanges between the organization and employees are grounds for a quality relationship. Thus, when employees feel they are not receiving beneficial treatment from the organization, they tend to feel aggravated, revengeful, and frustrated (Blau, 1964). Employees experiencing job-related tension tend to engage in deviant workplace behaviour because they are under the impression of not having any control of the source of tension (Fox, Spector \& Miles, 2001). Therefore, employees may get even by engaging in behaviour intended to harm the organization or other employees, or both (Yen \& Teng, 2013). This could be either by actively facing the source of tension (e.g. aggressive behaviour, threats) or react in a more subtle manner (e.g. avoid work, withdrawal). Allen \& Greenberg (1980) suggested that having the thought of being in control could be a determinant whether an employee engages in deviant workplace behaviour (Allen \& Greenberg, 1980). Since, job insecurity is a prolong uncertainty, thus it seems highly unlikely for an employee to have control over their jobs. This suggests that employees high in job-related tension were more likely to engage in deviant workplace behaviour. Therefore, this leads to the fourth hypothesis:

H4 There is a positive relationship between job-related tension and deviant workplace behaviour.

\section{The Moderating Effect of Emotional Intelligence on the Relationship between Job Insecurity and Affective Commitment}

Mayer and Salovey (1997) defined emotional intelligence as an individual's capability to identify emotions, to understand the reason of the emotions and finally being able to control the emotions (Mayer \& Salovey, 1997). Individuals who understand their emotions and able to control them are said to be more "emotionally intelligent" (Mayer \& Salovey, 1997). Job insecurity was reported to negatively affect an 
individual's well-being and lowered their level of affective commitment towards the organization (Sverke, 2004). However, because emotionally intelligent individuals have the ability to identify and handle their emotional reactions much better, they would be able to better cope with job insecurity since emotionally intelligent employees are able to assess the situation for both the positive and negative aspects and subsequently identify which emotion is appropriate to resolve the issue (Cheng et al., 2012). Thus, although job insecurity would generally decrease an employee's affective commitment, individuals who are emotionally intelligent remained to have high affective commitment even with the presence of job insecurity as they would be better at analysing the situation and solve the problem instead of letting their affective commitment to the organization be affected. For individuals with low emotional intelligence, their affective commitment will be lower with the sense of job insecurity as they perceive the situation from the negative point of view which leads to the feeling of stress and subsequently withdrawing themselves from the organization (Jordan et al., 2002). Therefore, it is expected that individuals who are emotionally intelligent will increase their affective commitment to the organization by portraying excitement in performing their work despite feeling job insecurity (Mayer \& Salovey, 1997). However, their lower emotional intelligent counterparts would more likely to experience low job performance and productivity due to the decreased level of affective commitment caused by job insecurity. Thus, the following hypothesis was proposed:

H5 Emotional intelligence moderates the relationship between job insecurity and affective commitment. High levels of emotional intelligence would be associated with a weaker job insecurity - affective commitment relationship.

\section{The Moderating Effect of Emotional Intelligence on the Relationship between Job Insecurity and Job-related Tension}

Emotionally intelligent individuals are able to handle their emotions effectively and productively resulting in a positive mental state during stressful circumstances (Singh, 2009). According to Singh (2009), emotional intelligence may be considered as the only differentiator when it comes to managing stress at workplace because emotionally intelligent individuals perceive and interpret a threatening environment in a different way that enables them to deal with emotions and emotional information effectively (Oginska-Bulik, 2005; Singh, 2009). This is because emotionally intelligent employees are able to appraise and determine the causes of their stress immediately once they feel the pressure and in consequence adopting the right coping mechanism (Ouyang, Sang, Li, \& Peng, 2015). Therefore, emotionally intelligent individuals will be able to manage their emotions effectively and efficiently even when faced with job insecurity resulting in lesser stress as compared to those low in emotional intelligence. This leads to the next hypothesis.

H6 Emotional intelligence moderates the relationship between job insecurity and job-related tension. High levels of emotional intelligence would be associated with a weaker job insecurity- job-related tension relationship. 


\section{The Moderating Effect of Emotional Intelligence on the Relationship between Affective Commitment and Deviant Workplace Behaviour; and Between Job- related Tension and Deviant Workplace Behaviour}

Slaski and Cartwright (2003) suggested in their study that emotional intelligence may influence the occurrence of aggressive behaviours caused by stress in the workplace. Similarly, Mayer et al. (2000) also found that emotional intelligence correlates negatively towards violent, bullying and trouble prone behaviours. These behaviours are among those that are conceptualized as deviant workplace behaviour. Highly emotional intelligent individuals are better at identifying the feeling of stress and differentiating between the various emotions that emerge as a result of that stressful situation therefore they are able to manage their emotions and respond appropriately (Ouyang et al., 2015). They are also capable of viewing the situation from various points of view before deciding which actions are best to handle the stressful situation (Jordan et al., 2002). Hence, they are able to cope with stressful situations by choosing from various coping strategies rather than submitting themselves to negative behaviours. When compared to their lower emotional intelligent counterparts, these individuals are more likely to cope with the stressful conditions (job insecurity) by withdrawing themselves from the organization, avoiding the problem and only performing the minimum requirement just to maintain their job (Jordan et al., 2002).

Based on the above, it is expected that the differences in one's emotional intelligence will affect their engagement in deviant workplace behaviour in a similar way where those higher in emotional intelligence are less likely to engage in deviant workplace behaviour in the presence of low affective commitment and higher job-related tension. As such, it is hypothesized that:

H7 Emotional intelligence moderates the relationship between affective commitment and deviant workplace behaviour. High levels of emotional intelligence would be associated with a weaker affective commitment - deviant workplace behaviour relationship.

H8 Emotional intelligence moderates the relationship between job-related tension and deviant workplace behaviour. High levels of emotional intelligence would be associated with a weaker job-related tension and deviant workplace behaviour relationship.

\section{Job Embeddedness as a Moderating Variable}

According to Burton et al. (2010), individuals who are greatly embedded in their job normally have a high degree of fit with the organization, have a lot of links within the organization and would have to give up certain aspects of their life if they decide to leave the organization. Besides that, highly embedded individuals are more involved in their organizations and have high expectations to remain in contact with colleagues or teams in the organizations (Sekiguchi et al., 2008). Also, it is reported that highly embedded individuals tend to be close-minded and are less affected by outside influences. Therefore, it is likely that the level of one's embeddedness in their job or organization influence how a person perceives negative events such as job insecurity and whether they should partake in deviant workplace behaviour. Following the above reasoning, with similar level of job-related tension, individuals with high job 
embeddedness are less likely to engage in deviant workplace behaviour as they would like to see their organization succeed in the future and continue to work without having to sacrifice loses if they quit the job. Alternatively, those with lower job embeddedness do not associate as closely to the organization, peers and not seeing much sacrifice leaving the organization, thus more likely to engage in deviant workplace behaviour.

H9 Job embeddedness moderates the relationship between job-related tension and deviant workplace behaviour. High levels of job embeddedness would be associated with a weaker job-related tension and deviant workplace behaviour relationship.

\section{Research Method}

\section{Samples and Procedures}

Primary data was collected in order to obtain the information needed for the analysis. Data was collected using self-administered questionnaire surveys which were mailed to the respective organizations. Mailing addresses were obtained from the Ministry of Human Resources. For each participating organization, a person in charge was responsible in distributing the survey to the employees in the organization. Prior to mailing the survey, phone calls were made to confirm their postal address and the person in charge of distributing the questionnaires to the employees. The researcher decided to use self-administrated questionnaire to collect data as it is cost effective because of the large sample size and the different geographical areas selected to conduct the study. The sample for this study were selected from organizations located in Johore, Penang and Selangor as these three states had the highest number of retrenchment cases in the country (Ministry of Human Resources, 2014). The respondents were from companies that had undergone retrenchment. Information on retrenchment statistics by state and category of occupation were obtained from the Ministry of Human Resources Malaysia (Ministry of Human Resources, 2014). The sample of respondents was selected from the three states with the highest number of retrenching companies. In this study, purposive sampling was used during data collection as judgment was imposed where sample was purposefully selected from employees working in retrenching organizations from the three highest states. The respondents were selected from a list of organizations that had undergone retrenchment in the year 2012 until June 2014 provided by the Ministry of Human Resources Malaysia. The total number of organizations in the retrenchment list of the three states was 180. All 180 organizations were then contacted by phone. Initially, only 24 organizations agreed to participate in the study when contacted and agreed to take in 10 questionnaires each. A second wave of questionnaires was sent out to 39 organizations that had declined initially but agreed to participate after further persuasion. In summary, 63 organizations participated in the study with 630 set of questionnaires being sent out. 
After two months of waiting period, each organization returned $4-6$ completed questionnaires via mail. This constituted a total of 247 completed questionnaires and a response rate of 39 percent. As shown in Table 1, majority of the respondents were aged between 26 to 35 years old (55\%) and 53\% of the respondents were male while $47 \%$ were female. 72 percent of the respondents held a bachelor degree. Half of the respondents were from Malay ethnicity (50\%), 30 percent were Chinese while the remaining 18 percent were Indians and 2 percent were from other ethnicity such as Sikh and Pakistani. Most of the respondent's present position in the company did not require them to supervise anybody (54\%) with only 2 percent from top management. Majority of the respondents (67\%) were from company with employees more than 1000.

Table 1: Demographic profile $(N=\mathbf{2 4 3})$

\begin{tabular}{|c|c|c|c|c|}
\hline \multicolumn{2}{|c|}{ Characteristics } & Frequency & Percent & Cumulative \% \\
\hline Age & \begin{tabular}{|l}
25 and below \\
$26-35$ \\
$36-45$ \\
45 and above \\
\end{tabular} & $\begin{array}{l}31 \\
133 \\
71 \\
8\end{array}$ & $\begin{array}{l}13 \\
55 \\
29 \\
3\end{array}$ & $\begin{array}{l}13 \\
68 \\
97 \\
100\end{array}$ \\
\hline Gender & $\begin{array}{l}\text { Male } \\
\text { Female }\end{array}$ & $\begin{array}{l}128 \\
115\end{array}$ & $\begin{array}{l}53 \\
47\end{array}$ & $\begin{array}{l}53 \\
100\end{array}$ \\
\hline $\begin{array}{l}\text { Education } \\
\text { Level }\end{array}$ & $\begin{array}{l}\text { SPM/STPM } \\
\text { Diploma } \\
\text { Bachelor's degree } \\
\text { Master's degree or higher }\end{array}$ & $\begin{array}{l}11 \\
42 \\
175 \\
15\end{array}$ & $\begin{array}{l}5 \\
17 \\
72 \\
6\end{array}$ & $\begin{array}{l}5 \\
22 \\
94 \\
100\end{array}$ \\
\hline Ethnicity & $\begin{array}{l}\text { Malay } \\
\text { Chinese } \\
\text { Indian } \\
\text { Others } \\
\end{array}$ & $\begin{array}{l}121 \\
73 \\
44 \\
5 \\
\end{array}$ & $\begin{array}{l}50 \\
30 \\
18 \\
2 \\
\end{array}$ & $\begin{array}{l}50 \\
80 \\
98 \\
100 \\
\end{array}$ \\
\hline $\begin{array}{l}\text { Present } \\
\text { Position }\end{array}$ & $\begin{array}{l}\text { I don't supervise anybody } \\
\text { First-line supervisor } \\
\text { Middle management } \\
\text { Top management } \\
\text { Others }\end{array}$ & $\begin{array}{l}131 \\
50 \\
54 \\
6 \\
2\end{array}$ & $\begin{array}{l}54 \\
21 \\
22 \\
2 \\
1\end{array}$ & $\begin{array}{l}54 \\
74 \\
97 \\
99 \\
100\end{array}$ \\
\hline $\begin{array}{l}\text { Company } \\
\text { Size }\end{array}$ & $\begin{array}{l}\text { Less than } 50 \text { employees } \\
50-100 \text { employees } \\
101-500 \text { employees } \\
501-1000 \text { employees } \\
\text { More than } 1000 \text { employees }\end{array}$ & $\begin{array}{l} \\
3 \\
38 \\
31 \\
162\end{array}$ & $\begin{array}{l}4 \\
1 \\
16 \\
13 \\
67\end{array}$ & $\begin{array}{l}4 \\
5 \\
21 \\
33 \\
100\end{array}$ \\
\hline
\end{tabular}




\section{Measures}

Job insecurity was measured by four items adapted from Caplan et al. (1975) with five-point Likert scale ( $1=$ extremely uncertain to $5=$ extremely certain). Some sample of the items were; 'How certain are you about your job security with this organization?' and 'How certain are you about what your future career picture looks like with this organization?'. The reliability of this construct was 0.73 (Ashford et al., 1989; Lim, 1996). In the final version of the questionnaire, the term 'job security' was used instead of 'job insecurity' as per the respondents' recommendations during the pilot study.

Affective commitment was captured by questions aimed to perceive on how much they feel belonged to the organization they work with. There were six questions which were developed by Meyer, Allen, and Smith (1993). Two of the items were; 'I feel a great sense of belonging to my organization' and 'I am proud to belong to this organization'. The items were measured on a five-point Likert scale ranging from 1 (strongly disagree) to 5 (strongly agree). The reliability of these six items was in the range of 0.85-0.91 (Morin et al., 2011).

Job-related tension was captured with a 15-item measure adapted from Kahn, Wolfe, Quinn, Snoek, and Rosenthal (1964). Two of the items were; 'Being unclear on just what the scope and responsibility of your job are' and 'Feeling that you're not fully qualified to handle your job'. The items were measured on a five-point Likert scale ranging from 1 (strongly disagree) to 5 (strongly agree).

Deviant workplace behaviour was measured with 12 items adapted from Robinson and Bennett (1995) and Peterson (2002) that intended to capture how often employees associate themselves with deviant workplace behaviour. Items included were; 'Blaming someone else or let someone else take the blame for your mistake' and 'repeated gossip about a co-worker'. These items were answered using six-point Likert scale which ranges from 1 (Never) to 5 (Always). Since the term deviant workplace behaviour was classified as a negative term during the pilot study, this study opted to remove the word 'deviant' and replaced it with 'workplace behaviour' in the final version of the questionnaire.

Emotional intelligence was measured with 33 items adapted from Schutte et al. (1998). Some of the items were; 'I know when to speak about my personal problems to others' and 'I find it hard to understand the non-verbal messages of other people'. These items were answered by a five-point Likert scale from 1 (strongly disagree) to 5 (strongly agree).

Job embeddedness was captured using 26 items adopted from Mitchell et al. (2001) whereby respondents responded with a five-point Likert scale ranging from 1 (strongly disagree) to 5 (strongly agree). Samples of the item were, 'I like members of my work group' and 'My job utilizes my skills and talents well'. 


\section{Analysis Procedures}

Data collected was analyzed quantitatively using Statistical Package for the Social Science (SPSS) version 20. Hypotheses testing were done with Partial Least Square Structural Equation Modelling (PLS-SEM) a multivariate modelling method using the software SmartPLS 2.0 to determine the impact of various simultaneous influences upon a single dependent variable and assess if there was any moderation relationship as hypothesized (Hair, Black, Babin \& Anderson, 2013). First, data was entered into SPSS (version 20.0) and data cleaning was done before any other analysis took place. Out of the 247 responses, four responses were deemed unusable due to missing values of more than 30 percent and therefore were excluded from the data set. Second, data concerning the number of years an employee had been in a present position, number of years they had worked in an organization and in the industry was transformed into a scale ranging from 1 to 5 . Third, the scoring for job-related tension which used a six-point Likert scale involved taking the average of all responses excluding the $6^{\text {th }}$ point (does not apply) by treating it as a missing value. Fourth, the mean substitution method for missing values was chosen in order to ensure all data set are complete so that SEM technique can be used. Lastly, the data was then examined for outliers and normality distribution properties which were identified by the skewness and kurtosis method.

Over the six months period of data collection, 630 questionnaires were distributed in two waves; 240 questionnaires in the first wave and 390 questionnaires in the second wave. Out of the targeted 630 questionnaires, 82 questionnaires were returned from the first wave and 161 questionnaires from the second wave of data collection. Although the overall response rate is above 30 percent (Armstrong \& Overton, 1977), non-response bias test was done to ensure no significant differences between respondents in wave 1 and 2 since there were examples of past studies where an increased response rate lead to greater bias (Merkle, Edelman, Dykeman \& Brogan, 1998). Independent Sample T-Test was conducted to compare the means of the main constructs. Result reported no significant differences between responses in wave 1 and 2 indicating that there was no non-response bias.

\section{Results}

\section{Measurement Model Results}

Confirmatory factor analysis (CFA) was conducted to assess the reliability, convergent validity and discriminant validity of the scales. It can be seen from Table 2 that the composite reliability (CR) values for job insecurity (0.84), affective commitment (0.83), job-related tension (0.89) and deviant workplace behaviour (0.88) surpasses the cut-off value for composite reliability of 0.708 . Also, the Cronbach's Alpha and rho_A values exceeds 0.7 in all constructs indicating internal consistency reliability. Next, the hierarchical measurement model was estimated. Two separate measurement model were tested which was the job-related tension (four dimensions) and workplace behaviour (four dimensions). All higher level constructs CR and AVE was in the acceptable range as suggested by Hair et al. (2013). Two indicators from construct job insecurity (JI5-0.50) and (AC5-0.53) and affective commitment were deleted in order to achieve acceptable AVE. The rest of the outer loadings were well 
above 0.5 . In addition, discriminant validity was ensured through the cross loadings assessment, Fornell-Larcker (1981) criterion and the Heterotrait-Monotrait ratio of correlations (HTMT). All indicators loaded highly on their respective construct. The square roots of constructs AVE were well above the constructs correlation with other latent variables in the measurement model. Additionally, the constructs met the

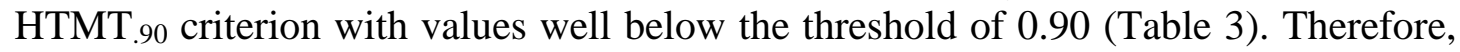
the measurement model met the requirement with the evidence of adequate reliability, convergent validity and discriminant validity.

Table 2: Measurement Model Assessment

\begin{tabular}{|c|c|c|c|c|c|c|}
\hline Constructs & Indicators & Loadings & AVE & $\begin{array}{c}\text { Cronbach's } \\
\text { Alpha }\end{array}$ & rho-A & $\mathbf{C R}$ \\
\hline \multirow[t]{5}{*}{ Job Insecurity } & JI1 & 0.73 & \multirow[t]{5}{*}{0.51} & \multirow[t]{5}{*}{0.75} & \multirow[t]{5}{*}{0.78} & \multirow[t]{5}{*}{0.84} \\
\hline & $\mathrm{JI} 2$ & 0.84 & & & & \\
\hline & JI3 & 0.8 & & & & \\
\hline & JI4 & 0.55 & & & & \\
\hline & JI6 & 0.62 & & & & \\
\hline \multirow[t]{5}{*}{ Affective Commitment } & $\mathrm{AC} 1$ & 0.58 & \multirow[t]{5}{*}{0.5} & \multirow[t]{5}{*}{0.74} & \multirow[t]{5}{*}{0.78} & \multirow[t]{5}{*}{0.83} \\
\hline & AC2 & 0.72 & & & & \\
\hline & AC3 & 0.86 & & & & \\
\hline & $\mathrm{AC} 4$ & 0.74 & & & & \\
\hline & AC6 & 0.58 & & & & \\
\hline \multirow[t]{4}{*}{ Job-Related Tension } & Performance & 0.86 & \multirow[t]{4}{*}{0.66} & \multirow[t]{4}{*}{0.87} & \multirow[t]{4}{*}{0.87} & \multirow[t]{4}{*}{0.89} \\
\hline & Workload & 0.84 & & & & \\
\hline & $\begin{array}{l}\text { Organizational } \\
\text { Design }\end{array}$ & 0.81 & & & & \\
\hline & $\begin{array}{l}\text { Decision } \\
\text { Making }\end{array}$ & 0.73 & & & & \\
\hline \multirow[t]{4}{*}{$\begin{array}{l}\text { Deviant Workplace } \\
\text { Behaviour }\end{array}$} & Production & 0.81 & \multirow[t]{4}{*}{0.64} & \multirow[t]{4}{*}{0.85} & \multirow[t]{4}{*}{0.86} & \multirow[t]{4}{*}{0.88} \\
\hline & Political & 0.77 & & & & \\
\hline & Property & 0.83 & & & & \\
\hline & Personal & 0.80 & & & & \\
\hline
\end{tabular}

Table 3: HTMT Results

\begin{tabular}{lccc}
\hline & $\begin{array}{c}\text { Affective } \\
\text { Commitment }\end{array}$ & $\begin{array}{c}\text { Deviant Workplace } \\
\text { Behaviour }\end{array}$ & Job Insecurity \\
\hline $\begin{array}{l}\text { Deviant Workplace } \\
\text { Behaviour }\end{array}$ & $\begin{array}{c}0.202 \\
\mathrm{CI}(0.195 ; 0.35)\end{array}$ & & \\
\hline Job Insecurity & 0.476 & 0.303 & \\
\hline Job-Related Tension & $\mathrm{CI}(0.342 ; 0.608)$ & $\mathrm{CI}(0.251 ; 0.451)$ & \\
& 0.286 & 0.513 & 0.323 \\
& $\mathrm{CI}(0.251 ; 0.414)$ & $\mathrm{CI}(0.415 ; 0.643)$ & $\mathrm{CI}(0.284 ; 0.436)$ \\
\hline
\end{tabular}




\section{Structural Model Results}

\section{Direct Relationships}

The structural model was tested for collinearity by conducting multiple regressions in SPSS. There was no collinearity issues among predictor constructs in this structural model since all values were below the standard value of 5 (Hair et al., 2013). Table 4 displays the path coefficients, standard errors, the t-values, the significance level as well as the confidence interval for the hypothesized direct relationship in the structural model. The effect size $\left(\mathrm{f}^{2}\right)$ and predictive relevance $\left(\mathrm{Q}^{2}\right)$ values are reported as well. The path coefficient value between job insecurity and affective commitment was significant $(\mathrm{t}>1.645)$ and in the expected direction $(-0.378, \mathrm{p}<.01)$ thus supporting H1. Likewise, the finding indicated that job insecurity was significantly (t $>1.645)$ related to job-related tension and the association was in the expected direction $(0.218, \mathrm{p}<.01)$. Therefore, hypothesis $\mathrm{H} 2$ was supported. On the other hand, the findings did not support $\mathrm{H} 3$ since the relationship between affective commitment and deviant workplace behaviour was not significant $(\mathrm{t}<1.645)$. In addition, the path coefficient between job-related tension and deviant workplace behaviour was significant $(\mathrm{t}>1.645)$ and in the expected direction $(0.437, \mathrm{p}<.01)$ providing support to $\mathrm{H} 4$. The effect size $\left(\mathrm{f}^{2}\right)$ shows that job-related tension $(0.24)$ has a substantive impact on the prediction of deviant workplace behaviour while affective commitment have no prediction value on deviant workplace behaviour. Additionally, job insecurity has a moderate prediction value $(0.15)$ on affective commitment and a weak prediction value $(0.05)$ on job-related tension.

Table 5 reveals the predictive relevance $\left(Q^{2}\right)$ and PLSpredict $\left(Q^{2}\right.$ predict $)$ results. The $Q^{2}$ values for all the endogenous constructs are above zero value indicating that the structural model has predictive relevance albeit modestly. Furthermore, the $\mathrm{Q}^{2}$ predict values for deviant workplace behaviour (key endogenous construct) is below zero value indicating that the model did not outperform the indicator means from the analysis sample (Shmueli et al., 2019). The prediction statistics shows that minority of indicators in the PLS SEM analysis yields higher prediction errors compared to the LM benchmark. This indicates that the model has medium predictive power (Shmueli et al., 2019).

Table 4: Direct Relationships in the Structural Model

\begin{tabular}{|c|c|c|c|c|c|c|c|c|c|}
\hline \multirow[b]{2}{*}{ H1 } & \multirow{2}{*}{$\begin{array}{c}\text { Relationships } \\
\text { JI -> AC }\end{array}$} & \multirow{2}{*}{$\begin{array}{c}\begin{array}{c}\text { Path } \\
\text { coefficients }\end{array} \\
-0.378\end{array}$} & \multirow{2}{*}{$\begin{array}{c}\begin{array}{c}\text { Std } \\
\text { error }\end{array} \\
0.055\end{array}$} & \multirow{2}{*}{$\begin{array}{c}\begin{array}{c}\text { t- } \\
\text { values }\end{array} \\
6.70\end{array}$} & \multirow{2}{*}{$\begin{array}{c}\text { Hypothesis } \\
\text { Supported }\end{array}$} & \multirow{2}{*}{$\begin{array}{l}\text { p-values } \\
0.00^{* * *}\end{array}$} & \multirow{2}{*}{$\begin{array}{c}\mathbf{f}^{2} \\
0.15\end{array}$} & \multicolumn{2}{|c|}{$\begin{array}{c}\text { Confidence } \\
\text { interval } \\
(95 \%) \\
\end{array}$} \\
\hline & & & & & & & & -0.465 & -0.289 \\
\hline H2 & $\mathrm{JI}->\mathrm{JRT}$ & 0.218 & 0.066 & 3.24 & Yes & $0.00^{* * * *}$ & 0.05 & 0.102 & 0.317 \\
\hline H3 & $\mathrm{AC} \rightarrow \mathrm{DWB}$ & -0.037 & 0.067 & 0.47 & No & 0.32 & 0 & -0.146 & 0.073 \\
\hline H4 & JRT -> DWB & 0.437 & 0.063 & 6.96 & Yes & $0.00^{* * * *}$ & 0.24 & 0.334 & 0.537 \\
\hline
\end{tabular}


Table 5: Results of $Q^{2}$ Values and PLS Predict

\begin{tabular}{lcc}
\hline Constructs & $\mathbf{Q}^{\mathbf{2}}$ values & PLS predict \\
\hline Affective Commitment & 0.06 & -0.221 \\
Job-Related Tension & 0.01 & -0.546 \\
Deviant Workplace Behaviour & 0.06 & -0.446 \\
\hline
\end{tabular}

\section{Moderating Effects of Emotional Intelligence and Job Embeddedness}

The path analysis in the structural model was extended to include emotional intelligence and job embeddedness as moderator variables. The outer model for both moderators was evaluated before further analysis and both were considered satisfactory with the evidence of adequate validity and reliability (Table 6). Testing moderators in PLS-SEM consists of a two-step analysis namely the PLS-SEM Algorithm and bootstrapping. First is to obtain the path coefficient value of the interaction term. Second, bootstrapping was applied to identify the significance of the interaction term. Table 7 reveals the outcome for both moderators.

Table 6: Assessment of Moderator Variables

\begin{tabular}{llccccc}
\hline \multicolumn{1}{c}{ Dimensions } & Loadings & AVE & $\begin{array}{c}\text { Cronbach's } \\
\text { Alpha }\end{array}$ & rho_A & CR \\
\hline $\begin{array}{l}\text { Emotional } \\
\text { Intelligence }\end{array}$ & $\begin{array}{l}\text { Perception of } \\
\text { emotions }\end{array}$ & 0.86 & 0.75 & 0.77 & 0.78 & 0.92 \\
& $\begin{array}{l}\text { Managing emotions } \\
\text { Managing other's }\end{array}$ & 0.91 & & 0.82 & 0.82 & \\
& $\begin{array}{l}\text { emotion } \\
\text { Emotion utilization }\end{array}$ & 0.91 & & 0.78 & 0.79 & \\
& factor & 0.79 & & 0.65 & 0.68 & \\
\hline Job & Fit & 0.91 & 0.65 & 0.826 & 0.843 & 0.85 \\
Embeddedness & Links & 0.68 & & 0.775 & 0.795 & \\
& Sacrifice & 0.82 & & 0.841 & 0.846 & \\
\hline
\end{tabular}

Table 7: Moderating Relationships in the Structural Model

\begin{tabular}{lcccccccc}
\hline & Relationships & $\begin{array}{c}\text { Path } \\
\text { Coefficients }\end{array}$ & $\begin{array}{c}\text { Std } \\
\text { error }\end{array}$ & $\begin{array}{c}\text { t- } \\
\text { values }\end{array}$ & $\begin{array}{c}\text { Hypothesis } \\
\text { Supported }\end{array}$ & $\begin{array}{c}\text { p- } \\
\text { values }\end{array}$ & $\begin{array}{c}\text { Confidence } \\
\text { interval } \\
(\mathbf{9 5 \%})\end{array}$ \\
\hline H5 & JI*EI -> AC & -0.058 & 0.081 & 0.715 & No & 0.24 & -0.342 & 0.047 \\
H6 & JI*EI -> JRT & 0.404 & 0.463 & 0.874 & No & 0.19 & -0.630 & 0.590 \\
H7 & AC*EI -> DWB & -0.299 & 0.146 & 2.043 & Yes & $0.02^{* *}$ & -0.469 & -0.097 \\
H8 & JRT $^{*}$ EI -> DWB & -0.247 & 0.116 & 2.134 & Yes & $0.03^{* *}$ & -0.344 & 0.366 \\
H9 & JRT $*$ JE -> DWB $^{*}-0.211$ & 0.073 & 2.362 & Yes & $0.02^{* *}$ & -0.273 & 0.040 \\
\hline
\end{tabular}

$\mathrm{DWB}=$ Deviant workplace behaviour, $\mathrm{EI}=$ Emotional intelligence, $\mathrm{JE}=\mathrm{J}$ ob embeddedness 
The interaction term of job insecurity and emotional intelligence holds a negative relationship towards affective commitment (-0.058). The analysis yields a t-value of $0.715(\mathrm{t}<1.645)$ for the path linking the interaction term and affective commitment concluding that emotional intelligence indicates insignificant moderating relationship. Hence, hypothesis H5 was not supported. Similarly, the data did not provide support for H6. Although the interaction term of job insecurity and emotional intelligence had a positive effect on job-related tension as predicted however the bootstrapping procedure generated a t-value of $0.874(\mathrm{t}<1.645)$ indicating an insignificant moderating effect. As for $\mathrm{H} 7$, the interaction term of affective commitment and emotional intelligence had a negative effect on deviant workplace behaviour (-0.299). The bootstrapping analysis yields a $t$-value of $2.043(\mathrm{t}>1.645)$ showing that the moderator effect was significant. It was suggested that affective commitment combined with emotional intelligence able to reduce deviant workplace behaviour by 0.299 units. (Refer to Figure 3 for the interaction plot). This was an interesting finding because there was no significant relationship between affective commitment and deviant workplace behaviour implying that affective commitment alone was not sufficient to bring down deviant workplace behaviour.

As seen in Figure 3, under low emotional intelligence situation, increases in affective commitment led to higher deviant workplace behaviour. In contrast, under high emotional intelligence situation, increases in affective commitment reduced deviant workplace behaviour. Moreover, the interaction term of job-related tension and emotional intelligence towards deviant workplace behaviour was a negative interaction (-0.247) with a t-value of $2.134(\mathrm{t}>1.645)$ indicating a significant moderating effect therefore providing support to H8. As shown in Figure 4, in the low emotional intelligence context, deviant workplace behaviour significantly increased when job-related tension increased. However, under high emotional intelligence context, deviant workplace behaviour would reduce even when job-related tension increased. Thus, emotional intelligence reduced the occurrence of deviant workplace behaviour even in the presence of job-related tension.

Figure 3: Interaction Plot for Affective Commitment and Emotional Intelligence

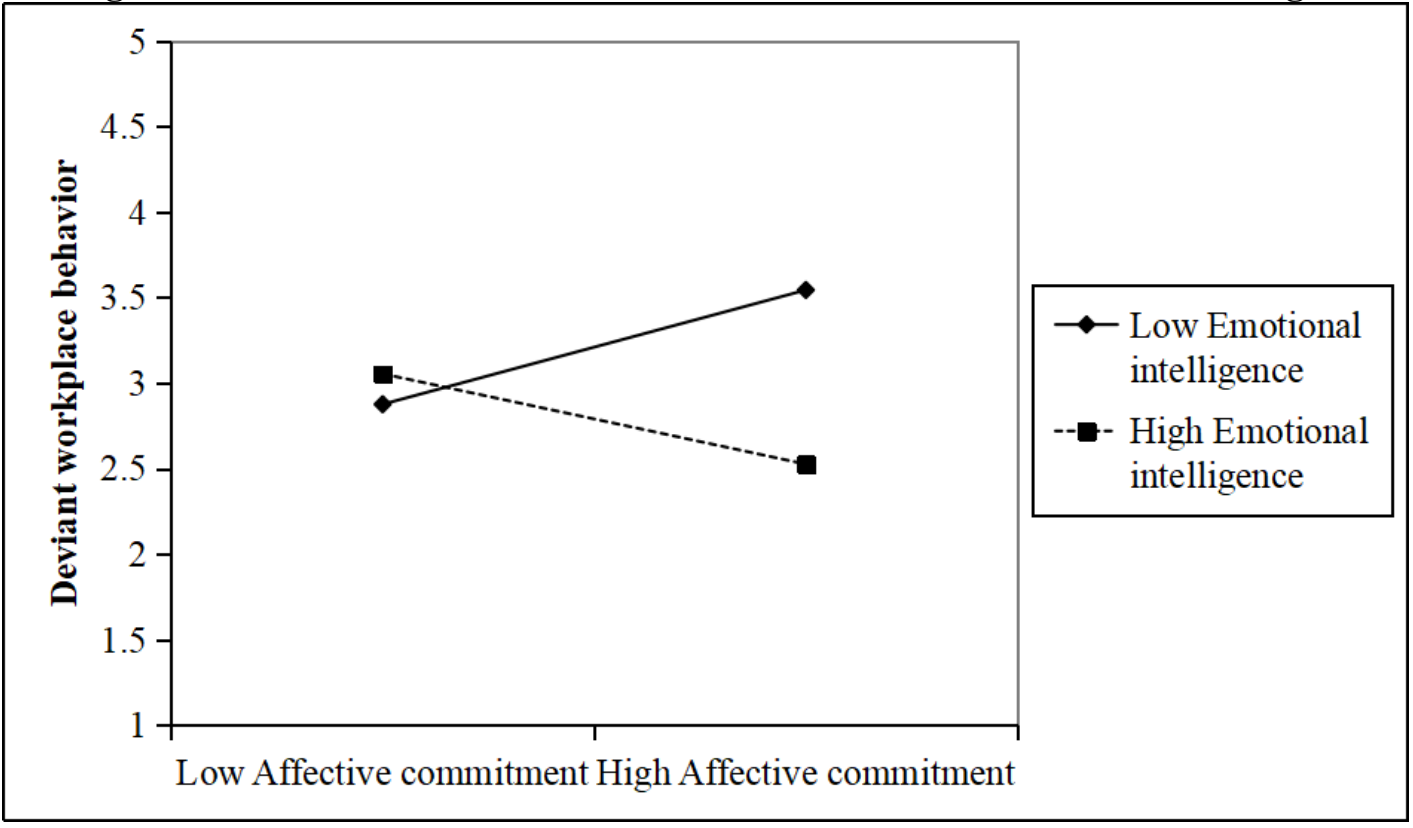


Figure 4: Interaction Plot for Job-Related Tension and Emotional Intelligence

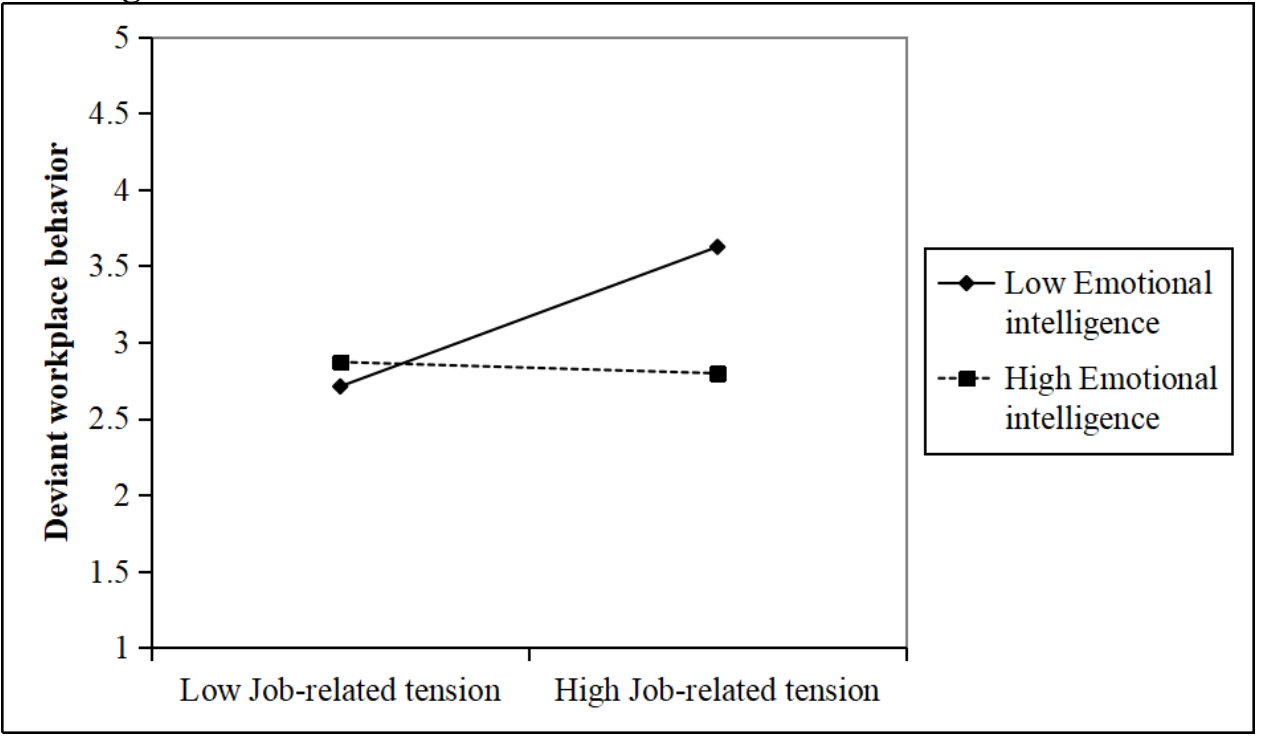

Turning to the analysis of the moderating effect of job embeddedness on the relationship between job-related tension and deviant workplace behaviour, the findings provided support to $\mathrm{H} 9$ such that job embeddedness reduced the probability of employees engaging in deviant workplace behaviour even when faced with high job-related tension. The interaction term of job embeddedness and job-related tension to deviant workplace behaviour had a negative value $(-0.211)$ towards deviant workplace behaviour and the bootstrapping procedure generated a t-value of $2.362(\mathrm{t}$ $>1.645$ ) indicating a significant moderating relationship. This result was graphically depicted in Figure 5. In high job embeddedness context, increase in job-related tension resulted in small increase in deviant workplace behaviour while in low job embeddedness context, increased in job-related tension resulted in large increase in deviant workplace behaviour.

Figure 5: Interaction Plot for Job-Related Tension and Job Embeddedness

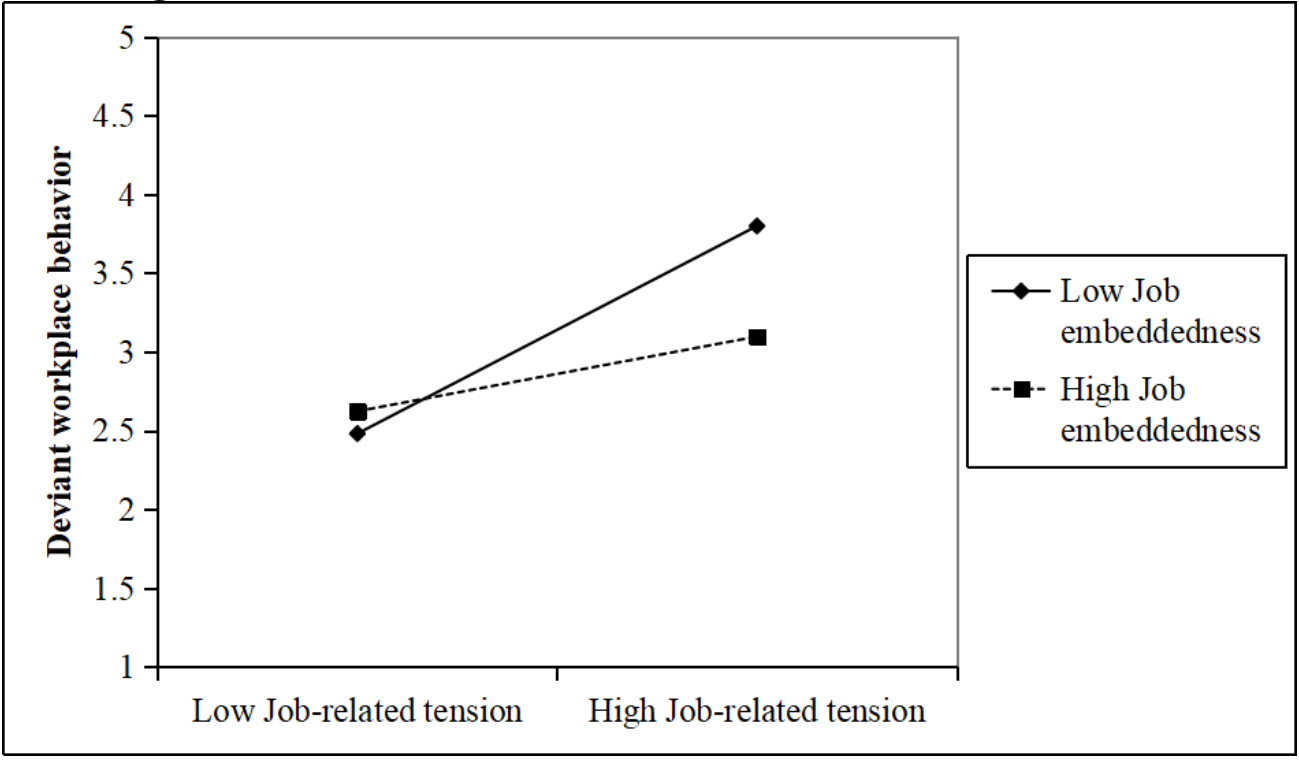




\section{Discussion}

This study investigated the manner in which job insecurity affect one's affective commitment and cause job-related tension. Also, this study explored the influence of affective commitment and job-related tension on deviant workplace behaviour. This study adapted the conceptual framework proposed by Jordan et al. (2002) in a bid to provide empirical evidence in explaining the antecedents of deviant workplace behaviour and exploring factors that are likely to buffer the adverse outcome of job insecurity. Out of the nine hypotheses proposed, six were supported by the data whilst three were not.

As theorized, this study found that job insecurity and affective commitment were negatively related. This finding was consistent with previous studies by Tian et al. (2014) and Kerse et al. (2018) that found a negative relationship between job insecurity and affective commitment in China and Turkey. Job insecurity elicited negative emotions leaving employees feeling afraid and uncertain about their jobs. Consequently, employees' emotional attachment to the organization was weakened and their level of affective commitment was reduced (Meyer \& Allen, 1997). Primarily, the result suggested that employees who experienced job insecurity lost confidence in the organization, which in turn reduced their attachment to the organization, their desire to work and also to remain productive for the benefit of their organization (Ashford et al., 1989; Meyer \& Herscovitch, 2001).

This study also found that job insecurity causes employee to experience job-related tension because of the uncertainty that it brings upon and employee's lack of control of the situation (Sverke, Hellgren \& Naswall, 2002). Job insecurity is an employee's internal appraisal of their work environment associated with the feeling of powerlessness and ambiguity concerning potential job loss. Since job insecurity is an experience felt by employees and with no actual event to it, therefore there would be no appropriate responses to it thus leaving employees feeling stressful (Burgard, Brand \& House, 2009). Studies on job insecurity have well documented it as a work stressor that causes negative job-related reactions and affects employees' psychological health (De Witte et al., 2016; Lee, Huang, \& Ashford, 2018; Llosa et al., 2018) as well as physical health (Henseke, 2018). Insecure employees have also been linked to depression, helplessness, anxiety, decreased positive affect and selfesteem (Sverke at al., 2002; Boya, Demiral, Ergor, Akvardar \& De Witte, 2008; Kim, Hong, Yook \& Kang, 2017).

Moreover, the findings did not reveal any significant directional relationship between affective commitment and deviant workplace behaviour indicating that affective commitment was not a significant predictor of deviant workplace behaviour. The result contradicted with past studies that reported deviant workplace behaviours to be among the adverse outcomes of low affective commitment (Gill et al., 2011; Tian et al., 2014). This discrepancy may be due to the respondents of this study that were employees from retrenching organizations whereas Gill et al. (2011) and Tian et al. (2014) sampled on employees from non-retrenching organizations. Employees who engaged in deviant workplace behaviour often were driven by the motivation to harm the welfare of the organization or its employee that had caused harm to them (Robinson \& Bennett, 1997). However, it could be possible that employees from retrenching organizations although having low affective commitment towards the 
organization, would not engage in deviant workplace behaviours probably because they were of the opinion that the organization's performance would be already compromised as a result of the downsizing exercise.

Furthermore, the result of this study provided evidence that job-related tension was positively associated with deviant workplace behaviour, supporting hypothesis 4 . The findings follow similar results from majority of the studies in the literature that the likelihood for employees to engage themselves in deviant workplace behaviour was higher in the presence of job-related tension (Penney \& Spector, 2005; Omar et al., 2011; Nasurdin et al., 2014; Farrastama, Asmony \& Hermanto, 2019). Employees experienced tension when they perceived themselves to be in an unpleasant situation that may possibly jeopardize their work goals, job activities or job performance (Penney \& Spector, 2005; Fida et al., 2015). Therefore, employees engaged in deviant workplace behaviour as a means of reducing the tension evoked by organizational stressors driven by the motivation to retaliate against the organization (Bowling \& Eschleman, 2010).

Employees with high level of emotional intelligence were expected to have high affective commitment despite feeling insecure as proposed in H5. However, results of this study did not provide support to this hypothesis. Since job insecurity is known to be one of the major stressors in a workplace therefore more aspect of individualdifference than just emotional intelligence is required to buffer the impact of job insecurity on affective commitment. Besides that, senior managers were reported to have higher level of emotional intelligence which was found to lead to higher level of affective commitment towards the organization (Carmeli, 2003). For that reason, the sample bias in this study may have contributed to an underestimation of the moderating role of emotional intelligence since only two percent of the respondents were from top management while the rest were employees from other organizational levels. Similarly, the data did not support H6 suggesting that emotional intelligence is a buffer in reducing the impact job insecurity has on job-related tension. This result was in line with earlier research (Ashford et al., 1989; Kinnunen, Mauno, Natti \& Happonen, 2000; Naswall et al., 2005) that because job insecurity is an impactful stressor and individual characteristic such as emotional intelligence plays only a mild role in reducing its impact on job-related tension.

The finding provided evidence that an employee's level of emotional intelligence reduces their tendency to engage in deviant workplace behaviour even when their affective commitment towards the organization was low. Although they do not or no longer feel emotionally attached to, identified with and involved in the organization (affective commitment), employees with high level of emotional intelligence were able to manage their emotions and regulate their moods efficiently (Mayer, Caruso, \& Salovey, 2000b). In view of that, emotionally intelligent employees were able to remain calm, energized and motivated to achieve their optimal outcome in the organization therefore were less likely to engage in deviant workplace behaviour (Craig, 2002; Lubit, 2003; Miao, Humphrey \& Qian, 2017). Also, the result was in line with previous research that reported employees with high levels of emotional intelligence engaged less in aggressive behaviour than their lower counterparts (Petrides, Frederickson \& Furnham, 2004; Miao et al., 2017). Thus, it is safe to say that in the presence of low affective commitment, highly emotional intelligence employees were able to cope with the situation by recognizing their emotions and 
react in a positive manner without succumbing to negative behaviours. Likewise, the result of this study confirmed that employees feeling job-related tension engaged less in deviant workplace behaviour if they had a high level of emotional intelligence. Being emotionally intelligent allowed them to understand their emotions and modify their behaviour in favour of optimizing their ability to achieve efficiency at work and managing stress (Matthews et al., 2006; Mohamed \& Nagy, 2017). For that reason, emotionally intelligent employees coped better with job-related tension as they thrived to maintain a positive state of mind therefore lessen the chances of submitting themselves to deviant workplace behaviour. This finding is parallel to past studies that found by being emotionally intelligent reduced the possibility of an employee to suffer from job-related stress as compared to those with lower emotional intelligence which consequently led to less aversive work behaviours (Nikolaou \& Tsaousis, 2002; Leong, Bullare Bahari, Malek \& Dahlan, 2019). Furthermore, emotionally intelligent employees were able to control their negative emotions to ensure that it does not negatively impact their work performance (Harvey \& Dasborough, 2006).

Moreover, the findings provided support that employees who were embedded in their job or organization have fewer tendencies to engage in deviant workplace behaviour although they suffered from job-related tension. One explanation could be that highly embedded individuals have multiple supports from which they can draw upon to alleviate their job-related tension whether it is support from family and friends (Hakanen, Perhoniemi \& Toppinen-Tanner, 2008), supervisors (Bakker, Schaufeli, Leiter \& Taris, 2008), co-workers (Halbesleben, 2010), or the organization in general (Eisenberger, Huntington, Hutchison \& Sowa, 1986). Besides, highly embedded employees were more attached to the organization thus were more motivated to maintain that bond rather than jeopardizing it (Hirschi, 1969). For that reason, highly embedded employees may engage in behaviours that are beneficial to the organization instead of partaking in deviant workplace behaviour. On the other hand, employees that were less embedded to the organization were more likely to retaliate by engaging in deviant workplace behaviour to express their dissatisfaction to the organization, more so in the presence of job-related tension (Burton et al., 2010).

\section{Managerial Implications}

This study provided evidence to support the propositions that job insecurity was negatively related to affective commitment and positively related to job-related tension. Moreover, job-related tension was found to be positively associated with deviant workplace behaviour while affective commitment did not indicate a significant relationship with deviant workplace behaviour. Taken together, these results suggest that job insecurity and job-related tension are antecedents of deviant workplace behaviour and deviant workplace behaviour is one of the consequences of job insecurity. This study contributes to the stress and coping literature by providing insight on the reason that employees displayed varying reactions when faced with job insecurity. Employee's level of emotional intelligence and their job embeddedness played a role as to whether the employees reacted to the job-related tension and reduced affective commitment by engaging in positive or negative actions. Furthermore, this study provided empirical evidence to the conceptual framework suggested by Jordan et al. (2002). The current data showed that emotional intelligence did not have any moderating role on job insecurity and its emotional reaction i.e. 
affective commitment and job-related tension. On the other hand, the findings of this study proved that emotional intelligence buffered the impact of affective commitment and job-related tension on deviant workplace behaviour which was a major contribution to the deviant behaviour literature. Moreover, the findings yield significant implication for the understanding of how job embeddedness can reduce deviant workplace behaviour when an employee experiences job insecurity. Specifically, the findings provided insight on the role of job embeddedness in the coping process of job-related tension.

Since job insecurity has been noted to affect an employee's level of affective commitment and their job-related tension, organization must be aware on the consequences of job insecurity and plan coping strategies with suitable management programs emphasizing on looking out for the employee's welfare. Such programs may include providing counsellors or encouraging managers to initiate a face-to-face session with employees so that they are able to express their emotions about the work situation. Managements may consider providing critical information regarding the retrenchment exercise such as; when will the retrenchment take place, the duration of the retrenchment and the retrenchment method that the organization opt for. These efforts indicate to the employees that the organization is committed in ensuring the employee's job security and career development with the organization. Besides that, organizations may formulate strategies that can strengthen employee's job embeddedness as a means of reducing employee's job-related tension.

\section{Further Research Directions}

This study has several limitations that warrant consideration. Firstly, the usage of selfreport questionnaire to assess deviant workplace behaviour may lead to common method bias since the responses were only obtained from one perspective, i.e. the employee. In addition, given the sensitivity of the subject matter employees tend to be discreet about their participation in deviant workplace behaviour without allowing coworkers or supervisors to know the degree of their involvement (Spector, 1994). Therefore, future studies should consider adopting supervisor ratings of deviant workplace behaviour to further test the hypotheses proposed in this study. Secondly, data collected by the self-reported questionnaires may have been subjected to social desirability bias since participants may respond in favour of portraying a good image specifically on items regarding deviant workplace behaviour. Hence, future studies are suggested to reduce the effect of social desirability bias by including the social desirability scale. Finally, predictors like job insecurity and affective commitment were reported having low effect size $\left(\mathrm{f}^{2}\right)$ on deviant workplace behaviour. Future studies might want to include variables like transformational leadership, moral disengagement, perceived organizational support and perceived organizational ethical values which may help to improve the effect size $\left(\mathrm{f}^{2}\right)$. We also acknowledge that our study being a quantitative study would not be able to provide the underlying reasons for the results of our study. What is now needed is a qualitative study to fully understand the implications of job insecurity and to obtain richer descriptions of the conditions when employees choose to engage in deviant workplace behaviour. 


\section{Conclusion}

Job insecurity has been frequently cited as a form of work-related stressor. As such, the result of this study reaffirms that employees perceive job insecurity as an organizational stressor. Through the findings it is found that job insecurity reduces employees' affective commitment towards the organization and heightens their jobrelated tension which motivate employees to engage in deviant workplace behaviour as a coping strategy to reduce the consequential negative emotions caused by the work stressor. This study also found that job-related tension precedes deviant workplace behaviour while affective commitment did not display any predictive value to deviant workplace behaviour. Therefore, to alleviate deviant workplace behaviour, organization should ensure that employees' job-related tensions are minimal. It is imperative to identify factors that may prevent employees from experiencing job insecurity or attenuate the negative effects caused by it; such factors may include moderating variables. This study discovered that emotional intelligence has moderating traits as proven in its relationship with affective commitment and deviant workplace behaviour; job-related tension and deviant workplace behaviour. However, emotional intelligence did not have any impact on job insecurity towards affective commitment and job-related tension. Meanwhile, job embeddedness alleviated the relationship between job-related tension and deviant workplace behaviour. Altogether, this study provides knowledge in what manner job insecurity may lead to deviant workplace behaviour i.e. through affective commitment and job-related tension plus factors that mitigate these relationships.

\section{Implications for Asian Business}

This study provided evidence that job insecurity negatively affects affective commitment and positively relates to job-related tension in organizations which have downsized. This study also confirms that job-related tension is associated with deviant workplace behaviour. Taken together, these results suggest that job insecurity and job-related tension are antecedents of deviant workplace behaviour and deviant workplace behaviour is one of the consequence job insecurity. Such information will be most useful to managers of organizations which are in the midst of planning or have undertaken downsizing activities. Based on the results of this study, managers of organizations which have downsized must plan coping strategies with suitable management programs emphasizing on looking out for the survivor's welfare. Such programs may include providing counsellors or encouraging managers to initiate faceto-face sessions with employees so that these employees (or "survivors") are able to express their emotions about the work situation. Management may consider providing critical information regarding the retrenchment exercise such as when will the retrenchment take place, the duration of the retrenchment and the retrenchment method that the organization opt for such efforts being made by the organizations is a way of communicating to the employees that the organization is committed to ensure the employee's job security and career development with the organization. 


\section{References}

Ahmadpour, N., (2014), "OCC model: Application and comparison to the dimensional model of emotion", In KEER2014: Proceedings of the 5th Kanesi Engineering and Emotion Research, International Conference, Linkoping, Sweden, no. 100, pp. 607-617.

Al Ghazo, R. H., Suifan, T. S., \& Alnuaimi, M., (2019), "Emotional intelligence and counterproductive work behaviour: The mediating role of organizational climate", Journal of Human Behaviour in the Social Environment, vol. 29, no. 3, pp. 333-345.

Allen, N. J., \& Meyer, J. P., (1990), "The measurement and antecedents of affective, continuance and normative commitment", Journal of Occupational Psychology, vol. 63, no. 1, pp. 1-18.

Allen, V. L., \& Greenberg, D. B., (1980), Destruction and perceived control in Baum, A., \& Singer, J., Advances in environmental psychology, Hillside, New Jersey.

Armstrong, J. S., \& Overton, T. S., (1977), "Estimating nonresponse bias in mail surveys", Journal of Marketing Research, vol. 14, no. 3, pp. 396-402.

Ashford, S. J., Lee, C., \& Bobko, P., (1989), "Content, causes, and consequences of job insecurity: A theory-based measure and substantive test", Academy of Management Journal, vol. 32, no. 4, pp. 803-829.

Bakker, A. B., Schaufeli, W. B., Leiter, M. P., \& Taris, T. W., (2008), "Work engagement: An emerging concept in occupational health psychology", Work \& Stress, vol. 22, no. 3, pp. 187-200.

Bennett, R. J., \& Robinson, S. L., (2000), "Development of a measure of workplace deviance", Journal of Applied Psychology, vol. 85, no. 3, pp. 349-360.

Blau, P. M., (1964), "Justice in social exchange", Sociological Inquiry, vol. 34, no. 2, pp. 193-206.

Boya, F. O., Demiral, Y., Ergor, A., Akvardar, Y., \& De Witte, H., (2008), "Effects of perceived job insecurity on perceived anxiety and depression in nurses", Industrial Health, vol. 46, no. 6, pp. 613-619.

Bowling, N. A., \& Eschleman, K. J., (2010), "Employee personality as a moderator of the relationships between work stressors and counterproductive work behaviour", Journal of Occupational Health Psychology, vol. 15, no. 1, pp. 91-103.

Burgard, S. A., Brand, J. E., \& House, J. S., (2009), "Perceived job insecurity and worker health in the United States", Social Science \& Medicine, vol. 69, no. 5, pp. 777-785.

Burton, J. P., Holtom, B. C., Sablynski, C. J., Mitchell, T. R., \& Lee, T. W., (2010), "The buffering effects of job embeddedness on negative shocks", Journal of Vocational Behaviour, vol. 76, no.1, pp. 42-51.

Caplan, R. D., Cobb, R. S., French, J. R. P. Jr, Van Harrison, R. V., \& Pinneau, S. R. Jr, (1975), Job demands and worker health: Main effects and occupational differences, U.S. Department of Health, Education and Welfare, Washington.

Carmeli, A., (2003), "The relationship between emotional intelligence and work attitudes, behaviour and outcomes: An examination among senior managers", Journal of Managerial Psychology, vol. 18, no. 8, pp. 788-813.

Cheng, T., Huang, G. H., Lee, C., \& Ren, X., (2012), "Longitudinal effects of job insecurity on employee outcomes: The moderating role of emotional intelligence and the leadermember exchange", Asia Pacific Journal of Management, vol. 29, no. 3, pp. 709-728.

Chirumbolo, A., (2015), "The impact of job insecurity on counterproductive work behaviours: The moderating role of honesty-humility personality trait", Journal of Psychology, vol. 149 , no. 6, pp. 554-569.

Chiu, S. F., \& Peng, J. C., (2008), "The relationship between psychological contract breach and employee deviance: The moderating role of hostile attributional style", Journal of Vocational Behaviour, vol. 73, no. 3, pp. 426-433.

Craig, J. A., (2002), It's not how smart you are, its how you are smart, Hara Publishing Group, London. 
Darrat, M. A., Amyx, D. A., \& Bennett, R. J., (2017), "Examining the impact of job embeddedness on salesperson deviance: The moderating role of job satisfaction', Industrial Marketing Management, vol. 63, pp. 158-166.

De Witte, H., (1999), "Job insecurity and psychological well-being: review of the literature and exploration of some unresolved issues", European Journal of Work and Organizational Psychology, vol. 8, no. 2, pp. 155-177.

De Witte, H., Pienaar, J., \& De Cuyper, N., (2016), "Review of 30 years of longitudinal studies on the association between job insecurity and health and well-being: Is there causal evidence?", Australian Psychologist, vol. 51, no. 1, pp. 18-31.

Eisenberger, R., Huntington, R., Hutchison, S., \& Sowa, D., (1986), "Perceived Organizational Support", Journal of Applied Psychology, vol. 71, no.3, pp. 500-507.

Farrastama, D. N., Asmony, T., \& Hermanto, H., (2019), "Effect of emotional intelligence on counterproductive work behaviour with job stress as an intervening variable", International Journal of Social Sciences and Humanities, vol. 3, no. 1, pp. 14-25.

Feng, D. D., Lu, C. Q., \& Siu, O. L., (2008), "Job insecurity, well-being, and job performance: The role of general self-efficacy", Acta Psychologica Sinica, vol. 40, no. 4, pp. 448-455.

Fida, R., Paciello, M., Tramontano, C., Fontaine, R. G., Barbaranelli, C., \& Farnese, M. L., (2015), "An integrative approach to understanding counterproductive work behaviour: The roles of stressors, negative emotions, and moral disengagement", Journal of Business Ethics, vol. 130, no. 1, pp. 131-144.

Fornell, C., \& Larcker, D. F., (1981), "Evaluating structural equation models with unobservable variables and measurement error", Journal of Marketing Research, vol. 18 , no. 1 , pp. 39-50.

Fox, S., Spector, P. E., \& Miles, D., (2001), "Counterproductive work behaviour (CWB) in response to job stressors and organizational justice: Some mediator and moderator tests for autonomy and emotions", Journal of Vocational Behaviour, vol. 59, no. 3, pp. 291309.

Gill, H., Meyer, J. P., Lee, K., Shin, K. H., \& Yoon, C. Y., (2011), "Affective and continuance commitment and their relations with deviant workplace behaviours in Korea", Asia Pacific Journal of Management, vol. 28, no. 3, pp. 595-607.

Greene, J., Mero, N., \& Werner, S., (2018), "The negative effects of job embeddedness on performance", Journal of Managerial Psychology, vol. 33, no. 1, pp. 58-73.

Grossi, E. L., Keil, T. J., \& Vito, G. F., (1996), "Surviving 'the joint': Mitigating factors of correctional officer stress", Journal of Crime and Justice, vol. 19, no. 2, pp. 103-120.

Hair, J. F., Black, W. C., Babin, B. J., \& Anderson, R. E., (2013), Multivariate data analysis, Prentice Hall, New Jersey.

Hakanen, J. J., Perhoniemi, R., \& Toppinen-Tanner, S., (2008), "Positive gain spirals at work: From job resources to work engagement, personal initiative and work-unit innovativeness", Journal of Vocational Behaviour, vol. 73, no. 1, pp. 78-91.

Halbesleben, J. R., (2010), A meta-analysis of work engagement: Relationships with burnout, demands, resources, and consequences, In Bakker, A. B., \& Leiter, M. P., Work engagement: A handbook of essential theory and research, Psychology Press, Hove.

Henseke, G., (2018), "Good jobs, good pay, better health? The effects of job quality on health among older European workers", European Journal of Health Economics, vol. 19, no. 1, pp. 59-73.

Harvey, P., \& Dasborough, M. T., (2006), "Consequences of employee attributions in the workplace: The role of emotional intelligence", Psicothema, vol. 18, pp. 145-151.

Hill, N., (2004), Think and grow rich, revised and expanded by A. R. Pell, Vermilion, London.

Hirschi, T., (1969), Causes of delinquency, University of California Press, Berkeley.

Huang, G. H., Lee, C., Ashford, S., Chen, Z., \& Ren, X., (2010), "Affective job insecurity: A mediator of cognitive job insecurity and employee outcomes relationships", International Studies of Management \& Organization, vol. 40, no. 1, pp. 20-39. 
Huy, Q. N., (1999), "Emotional capability, emotional intelligence, and radical change", Academy of Management Review, vol. 24, no. 2, pp. 325-345.

Ito, J. K., \& Brotheridge, C. M., (2007), "Exploring the predictors and consequences of job insecurity's components", Journal of Managerial Psychology, vol. 22, no. 1, pp. 40-64.

Jex, S. M., \& Beehr, T. A., (1991), "Emerging theoretical and methodological issues in the study of work-related stress", Research in Personnel and Human Resources Management, vol. 9, no. 31, pp. 1-365.

Jordan, P. J., Ashkanasy, N. M., \& Hartel, C. E., (2002), "Emotional intelligence as a moderator of emotional and behavioural reactions to job insecurity", Academy of Management Review, vol. 27, no. 3, pp. 361-372.

Kahn, R. L., Wolfe, D. M., Quinn, R. P., Snoek, J. D., \& Rosenthal, R. A., (1964), Organizational stress: Studies in role conflict and ambiguity, Wiley \& Sons, New York.

Kerse, G., Kocak, D., \& Ozdemir, S., (2018), "Does the perception of job insecurity bring emotional exhaustion? The relationship between job insecurity, affective commitment and emotional exhaustion", Business and Economics Research Journal, vol. 9, no. 3, pp. 651-664.

Kim, M. S., Hong, Y. C., Yook, J. H., \& Kang, M. Y., (2017), "Effects of perceived job insecurity on depression, suicide ideation, and decline in self-rated health in Korea: A population-based panel study", International Archives of Occupational and Environmental Health, vol. 90, no. 7, pp. 663-671.

Kinnunen, U., Mauno, S., Natti, J., \& Happonen, M., (2000), "Organizational antecedents and outcomes of job insecurity: A longitudinal study in three organizations in Finland", Journal of Organizational Behaviour, vol. 21, no. 4, pp. 443-459.

Konig, C. J., Debus, M. E., Hausler, S., Lendenmann, N., \& Kleinmann, M., (2010), "Examining occupational self-efficacy, work locus of control and communication as moderators of the job insecurity-job performance relationship", Economic and Industrial Democracy, vol. 31, no. 2, pp. 231-247.

Konig, C. J., Probst, T. M., Staffen, S., \& Graso, M., (2011), “A Swiss-U.S. comparison of the correlates of job insecurity", Applied Psychology, vol. 60, no. 1, pp. 141-159.

Lambert, E. G., Minor, K. I., Wells, J. B., \& Hogan, N. L., (2016), "Social support's relationship to correctional staff job stress, job involvement, job satisfaction, and organizational commitment", The Social Science Journal, vol. 53, no. 1, pp. 22-32.

Lawrence, T. B., \& Robinson, S. L., (2007), "Ain't misbehaving: Workplace deviance as organizational resistance", Journal of Management, vol. 33, no. 3, pp. 378-394.

Lazarus, R. S., \& Folkman, S., (1984), Stress, appraisal, and coping, Springer Publishing Company, New York.

Lee, C., Huang, G. H., \& Ashford, S. J., (2018), “Job insecurity and the changing workplace: Recent developments and the future trends in job insecurity research", Annual Review of Organizational Psychology and Organizational Behaviour, vol. 5, pp. 335-359.

Leong, J. J., Bullare Bahari, M. I., Malek, M., \& Dahlan, A., (2019), "The effects of emotional intelligence on job stress among the enforcement officers", Education Sciences \& Psychology, vol. 52, no. 2, pp. 44-54.

Lim, V. K., (1996), "Job insecurity and its outcomes: Moderating effects of work-based and non-work-based social support", Human Relations, vol. 49, no. 2, pp. 171-194.

Lin, X. S., Chen, Z. X., Ashford, S. J., Lee, C., \& Qian, J., (2018), "A self-consistency motivation analysis of employee reactions to job insecurity: The roles of organizationbased self-esteem and proactive personality", Journal of Business Research, vol. 92, pp. 168-178.

Llosa, J. A., Menendez-Espina, S., Agullo-Tomas, E., \& Rodriguez-Suarez, J., (2018), “Job insecurity and mental health: A meta-analytical review of the consequences of precarious work in clinical disorders", Anales de Psicología, vol. 34, no. 2, pp. 211221. 
Lubit, R. H., (2003), Coping with toxic managers, subordinates and other difficult people: Using emotional intelligence to survive and prosper, FT Prentice Hall, New Jersey.

Mak, A. S., \& Mueller, J., (2000), "Job insecurity, coping resources and personality dispositions in occupational strain", Work \& Stress, vol. 14, no. 4, pp. 312-328.

Makikangas, A., \& Kinnunen, U., (2003), "Psychosocial work stressors and well-being: Selfesteem and optimism as moderators in a one-year longitudinal sample", Personality and Individual Differences, vol. 35, no. 3, pp. 537-557.

Martin, J., Knopoff, K., \& Beckman, C., (1998), "An alternative to bureaucratic impersonality and emotional labour: Bounded emotionality at The Body Shop", Administrative Science Quarterly, vol. 43, no. 2, pp. 429-469.

Matthews, G., Emo, A. K., Funke, G., Zeidner, M., Roberts, R. D., Costa Jr, P. T., \& Schulze, R., (2006), "Emotional intelligence, personality, and task-induced stress", Journal of Experimental Psychology: Applied, vol. 12, no. 2, pp. 96-107.

Mayer J. D., Salovey P., \& Caruso, D. R., (2000), Emotional intelligence as zeitgeist, as personality, and as a standard intelligence, in Bar-On, R., \& Parker, J. D. A., The handbook of emotional intelligence, Jossey-Bass, New York.

Mayer, J. D., \& Salovey, P., (1997), What is emotional intelligence?, in Salovey, P., \& Sluyter, D. J., Emotional development and emotional intelligence: Educational implications, Basic Books, New York.

Mayer, J. D., Caruso, D. R, \& Salovey, P., (2000b), Models of emotional intelligence, in Sternberg, R. J., The handbook of intelligence, Cambridge University Press, Cambridge.

Menendez-Espina, S., Llosa, J. A., Agullo-Tomas, E., Rodriguez-Suarez, J., Saiz-Villar, R., \& Lahseras-Diez, H. F., (2019), "Job insecurity and mental health: The moderating role of coping strategies from a gender perspective", Frontiers in Psychology, vol. 10, pp. 110.

Merkle, D., Edelman, M., Dykeman, K., \& Brogan, C., (1998), “An experimental study of ways to increase exit poll response rates and reduce survey error", Annual Conference of the American Association for Public Opinion Research, St. Louis, Missouri.

Meyer, J. P., \& Herscovitch, L., (2001), "Commitment in the workplace: Toward a general model”, Human Resource Management Review, vol. 11, no. 3, pp. 299-326.

Meyer, J. P., Allen, N. J., \& Smith, C. A., (1993), "Commitment to organizations and occupations: Extension and test of a three-component conceptualization", Journal of Applied Psychology, vol. 78, no. 4, pp. 538-551.

Meyer, J. P., Stanley, D. J., Herscovitch, L., \& Topolnytsky, L., (2002), “Affective, continuance, and normative commitment to the organization: A meta-analysis of antecedents, correlates, and consequences", Journal of Vocational Behaviour, vol. 61, no. 1 , pp. 20-52.

Meyer, J. P., \& Allen, N. J., (1997), Commitment in the workplace: Theory, research, and application, Sage Publications, Thousand Oaks.

Miao, C., Humphrey, R. H., \& Qian, S., (2017), "Are the emotionally intelligent good citizens or counterproductive? A meta-analysis of emotional intelligence and its relationships with organizational citizenship behaviour and counterproductive work behaviour", Personality and Individual Differences, vol. 116, pp. 144-156.

Mitchell, T. R., Holtom, B. C., Lee, T. W., Sablynski, C. J., \& Erez, M., (2001), "Why people stay: Using job embeddedness to predict voluntary turnover", Academy of Management Journal, vol. 44, no. 6, pp. 1102-1121.

Mohamed, S. M., \& Nagy, F., (2017), "Emotional intelligence and job stress among academic members at faculty of nursing-Cairo University", Journal of Nursing and Health Science, vol. 6, pp. 10-9.

Morin, A. J., Vandenberghe, C., Boudrias, J. S., Madore, I., Morizot, J., \& Tremblay, M., (2011), "Affective commitment and citizenship behaviours across multiple foci", Journal of Managerial Psychology, vol. 26, no. 8, pp. 716-738.

Murphy, W. M., Burton, J. P., Henagan, S. C., \& Briscoe, J. P., (2013), "Employee reactions to job insecurity in a declining economy: A longitudinal study of the mediating role of job embeddedness", Group \& Organization Management, vol. 38, no. 4, pp. 512-537. 
Nasurdin, A. M., Ahmad, N. H., \& Razalli, A. A., (2014), "Politics, justice, stress, and deviant behaviour in organizations: An empirical analysis", International Journal of Business and Society, vol. 15, no. 2, pp. 235-254.

Naswall, K., Sverke, M., \& Hellgren, J., (2005), "The moderating role of personality characteristics on the relationship between job insecurity and strain", Work \& Stress, vol. 19 , no. 1, pp. 37-49.

Nikolaou, I., \& Tsaousis, I., (2002), "Emotional intelligence in the workplace: Exploring its effects on occupational stress and organizational commitment", The International Journal of Organizational Analysis, vol. 10, no. 4, pp. 327-342.

Oginska-Bulik, N., (2005), "Emotional intelligence in the workplace: Exploring its effects on occupational stress and health outcomes in human service workers", International Journal of Occupational Medicine and Environmental Health, vol. 18, no. 2, pp. 167175.

Omar, F., Halim, F., Zainah, A., \& Farhadi, H., (2011), "Stress and job satisfaction as antecedents of workplace deviant behaviour", Deviant Behaviour, vol. 16, p. 17.

Oplatka, I., (2009), "Organizational citizenship behaviour in teaching: The consequences for teachers, pupils, and the school", International Journal of Educational Management, vol. 23 , no. 5 , pp. 375-389.

Ortony, A., Clore, G. L., \& Collins, A., (1990), The cognitive structure of emotions, Cambridge University Press, New York.

Ouyang, Z., Sang, J., Li, P., \& Peng, J., (2015), "Organizational justice and job insecurity as mediators of the effect of emotional intelligence on job satisfaction: A study from China", Personality and Individual Differences, vol. 76, pp. 147-152.

Panaccio, A., Vandenberghe, C., \& Ben Ayed, A. K., (2014), "The role of negative affectivity in the relationships between pay satisfaction, affective and continuance commitment and voluntary turnover: A moderated mediation model", Human Relations, vol. 67, no. 7, pp. 821-848.

Penney, L. M., \& Spector, P. E., (2005), "Job stress, incivility, and counterproductive work behavior (CWB): The moderating role of negative affectivity", Journal of Organizational Behaviour, vol. 26, no. 7, pp. 777-796.

Peterson, D. K., (2002), "Deviant workplace behaviour and the organization's ethical climate", Journal of Business and Psychology, vol. 17, no.1, pp. 47-61.

Petrides, K. V., Frederickson, N., \& Furnham, A., (2004), "The role of trait emotional intelligence in academic performance and deviant behaviour at school", Personality and Individual Differences, vol. 36, no. 2, pp. 277-293.

Probst, T. M., \& Lawler, J., (2006), "Cultural values as moderators of employee reactions to job insecurity: The role of individualism and collectivism", Applied Psychology: An International Review, vol. 55, no. 2, pp. 234-254.

Promsri, C., (2018), "The effects of organizational commitment on deviant work behaviours of employees at a Thai government bank", Social Science and Humanities Journal, vol. 2, no. 3, pp. 370-377.

Robinson, M. D., Persich, M. R., Stawicki, C., \& Krishnakumar, S., (2019), "Deviant workplace behaviour as emotional action: Discriminant and interactive roles for workrelated emotional intelligence", Human Performance, vol. 32, no. 5, pp. 201-219.

Robinson, S. L., \& Bennett, R. J., (1995), "A typology of deviant workplace behaviours: A multidimensional scaling study", Academy of Management Journal, vol. 38, no. 2, pp. 555-572.

Robinson, S. L., \& Bennett, R. J., (1997), "Workplace deviance: Its definition, its manifestations, and its causes", In Lewicki, R. J., Bies, R. J., \& Sheppard, B. H., Research on Negotiation in Organizations, vol. 6, pp. 3-27.

Roskies, E., Louis-Guerin, C., \& Fournier, C., (1993), "Coping with job insecurity: How does personality make a difference?", Journal of Organizational Behaviour, vol. 14, no. 7, pp. 617-630. 
Safaria, T., Othman, A., \& Wahab, M. N. A., (2011), "Role ambiguity, role conflict, the role of job insecurity as mediator toward job stress among Malay academic staff: A SEM analysis", Current Research Journal of Social Sciences, vol. 3, no. 3, pp. 229-235.

Samnani, A. K., Salamon, S. D., \& Singh, P., (2014), "Negative affect and counterproductive workplace behaviour: The moderating role of moral disengagement and gender", Journal of Business Ethics, vol. 119, no. 2, pp. 235-244.

Schutte, N. S., Malouff, J. M., Hall, L. E., Haggerty, D. J., Cooper, J. T., Golden, C. J., \& Dornheim, L., (1998), "Development and validation of a measure of emotional intelligence", Personality and Individual Differences, vol. 25, no. 2, pp. 167-177.

Sekiguchi, T., Burton, J. P., \& Sablynski, C. J., (2008), "The role of job embeddedness on employee performance: The interactive effects with leader-member exchange and organization-based self-esteem", Personnel Psychology, vol. 61, no. 4, pp. 761-792.

Selenko, E., Makikangas, A., \& Stride, C. B., (2017), "Does job insecurity threaten who you are? Introducing a social identity perspective to explain well - being and performance consequences of job insecurity", Journal of Organizational Behaviour, vol. 38, no. 6, pp. 856-875.

Shmueli, G., Sarstedt, M., Hair, J. F., Cheah, J. H., Ting, H., Vaithilingam, S., \& Ringle, C. M., (2019), "Predictive model assessment in PLS-SEM: Guidelines for using PLSpredict", European Journal of Marketing, vol. 53, no. 11, pp. 2322-2347.

Silva, H. M .S., \& Ranasinghe, R. M. I. D., (2017), "The impact of job stress on deviant workplace behaviour: A study of operational level employees of comfort apparel solutions company in Sri Lanka", International Journal of Human Resource Studies, vol. 7, no. 1, pp. 74-85.

Singh, S. K., (2009), "Leveraging emotional intelligence for managing executive's job stress: A framework", Indian Journal of Industrial Relations, vol. 45, no. 2, pp. 255-264.

Siu, O. L., (2013), "The adverse effects of recession-related events on the health and wellbeing of individuals" in Cooper C. L., \& Antoniou, A. S., The psychology of the recession on the workplace, Edward Elgar Publishing, Cheltenham.

Slaski, M., \& Cartwright, S., (2003), "Emotional intelligence training and its implications for stress, health and performance", Stress and Health, vol. 19, no. 4, pp. 233-239.

Spector, P. E., (1994), "Using self-report questionnaires in OB research: A comment on the use of a controversial method", Journal of Organizational Behaviour, vol. 15, no. 5, pp. 385-392.

Spector, P. E., \& Fox, S., (2002), “An emotion-cantered model of voluntary work behaviour: Some parallels between counterproductive work behaviour and organizational citizenship behaviour", Human Resource Management Review, vol. 12, no. 2, pp. 269292.

Susomrith, P., \& Amankwaa, A., (2019), "Relationship between job embeddedness and innovative work behaviour", Management Decision, In-press.

Sverke, M., Hellgren, J., \& Naswall, K., (2002), "No security: A meta-analysis and review of job insecurity and its consequences", Journal of Occupational Health Psychology, vol. 7, no. 3, pp. 242-264.

Sverke, M., (2004), Job insecurity and union membership: European Unions in the wake of flexible production, P.I.E.-Peter Lang, Brussels.

Thoresen, C. J., Kaplan, S. A., Barsky, A. P., Warren, C. R., \& de Chermont, K., (2003), “The affective underpinnings of job perceptions and attitudes: A meta-analytic review and integration", Psychological Bulletin, vol. 129, no. 6, pp. 914-945.

Tian, Q., Zhang, L., \& Zou, W., (2014), "Job insecurity and counterproductive behaviour of casino dealers-the mediating role of affective commitment and moderating role of supervisor support", International Journal of Hospitality Management, vol. 40, pp. 2936.

Van Graan, F., (1981), "Werkspanning: Bedryfpsigologiese ondersoek", Doctoral Dissertation, Potchefstroom University, Vanderbijlpark. 
Van Voorhis, P., Cullen, F. T., Link, B. G., \& Wolfe, N. T., (1991), "The impact of race and gender on correctional officers' orientation to the integrated environment", Journal of Research in Crime and Delinquency, vol. 28, no. 4, pp. 472-500.

Van Zyl, L., Van Eeden, C., \& Rothmann, S., (2013), "Job insecurity and the emotional and behavioural consequences thereof", South African Journal of Business Management, vol. 44, no. 1, pp. 75-86.

Yam, L., \& Raybould, M., (2019), "Exploring the job embeddedness construct as a predictor of intention to leave in hospitality workers", In The 3rd International Conference on Tourism and Business 2019.

Yen, C. H., \& Teng, H. Y., (2013), "The effect of centralization on organizational citizenship behaviour and deviant workplace behaviour in the hospitality industry", Tourism Management, vol. 36, pp. 401-410. 